\title{
FACTORS INFLUENCING THE LABOUR PRODUCTIVITY IN DAIRY SECTOR IN EU
}

\author{
Radek ZDENĚK ${ }^{* 1}$, Jana LOSOSOV $\dot{A}^{1}$
}

\author{
Address: \\ ${ }^{1}$ University of South Bohemia in České Budějovice, Department of Finance and Accounting, Faculty of Economic, Studentská 13,37005 České \\ Budějovice, Czech Republic \\ *Corresponding author: zdenek@ef.jcu.cz
}

\begin{abstract}
The most important for the stability of Europe and Czech milk market is to remain competitive in world markets, as the main way for balance on the internal market is based on successful export of dairy products to third countries. Price volatility and environmental sustainability are seen as the most serious current problems in the dairy industry and dairy farming. The aim of this paper is to assess the development of the production and milk prices in the EU and assess the main factors that affect labour productivity. The number of cows per worker is one of the most important factors affecting labour productivity. Effect of prices on labour productivity in monetary expression is not as significant as is usually assumed. The technical equipment of labour should be an important factor influencing the number of cows per worker. The hypothesis that higher technical equipment of labour should create better conditions for higher productivity could be assumed.
\end{abstract}

Keywords: labour productivity, milk price, milk yield JEL: Q11, Q14

\section{INTRODUCTION}

By the International Farm Comparison Network (IFCN) estimate, about 122 million dairy farms take part in milk production with 363 million of dairy cows. That means that an average farmer has 3 dairy livestock animals with average annual milk yield of $2100 \mathrm{~kg}$ per animal and year. According to the outlook for the next 10 years, the world price of milk will reach 44.5 USD per $100 \mathrm{~kg}$ of milk. World milk production in 2023 will reach the level of 1000 million tons, while it amounted to 780 million tons in 2012. The demand for milk will increase in 2023 by $29 \%$ (more than 20 million tons per year). There will be an increase in global trade in milk and milk products, so that growing demand will be met by imports to a greater extent than before. The largest exporter of milk will be New Zealand and the EU. China and Russia will be the largest importer (IFCN, 2013).

The growth of the demand is significantly supported by the growing demand in south-east Asia. The popularity of dairy products, western eating habits and expanding range of dairy products are the most important support of growth in world dairy markets. Continued expansion of world demand is given by the rising global population and economic growth. This situation should increase exports of the European Union and lead to the maintenance of prices of major dairy commodities, so the prospects for dairy farming and the dairy industry in the EU for the next 10 years appear to be favourable. The European Union produces about $10 \%$ of the milk more than its total domestic consumption. The most important for the stability of Europe and therefore the Czech milk market is to remain competitive in world markets, as the main pathway for overproduction and balance on the internal market is based on successful export of dairy products to third countries. The European Commission does not foresee any major shocks in connection with the termination of the milk quota at 31 March 2015 (Ministry of Agriculture [MZe], 2014). Price volatility and environmental sustainability are seen as the most serious current problems in the dairy industry and dairy farming. The strategic conference of DG AGRI held on 24 September 2013 in Brussels brought participant in the dairy chain and representatives of the EU institutions, Member States and experts from research and economic entities together. The aim of the conference was to explore new challenges and likely developments, which will the milk in the EU face and the discussion on the necessity of introducing an additional tool with regard to the termination of the quota system in 2015. The real risk of high prices fall and the importance of keeping the Europe's competitiveness on world markets were presented there. The future of milk production in Europe should be the increase of farms with more than 100 of dairy cows. There is also the need for the establishment of a monitoring agency and a number of other measures. The conference suggests that the greatest impact on the outlook for the dairy sector is related to global input prices, output and demand (European Commission [EC], 2014). 
Labour productivity is an important factor influencing the economic performance of an enterprise. The aim of this paper is to assess the development of the production and milk prices in the EU. The main part of the paper deals with the important factors that affect labour productivity and so they can explain the differences in labour productivity of dairy farms among the European states.

\section{MATERIAL AND METHODS}

According to Doubek et al. (2012) Czech producers have to deal with unequal competition of subventions and in fact dumping import prices in all market areas with agricultural and food products. The authors say that is evident that achieving a minimum return of various agricultural commodities is essentially an exception. They say that the vast majority of agricultural products are not cost-effective for primary agricultural producers. The sharp decline in the number of livestock in all categories will cause far-reaching structural changes in the future, which could affect the overall stability of the biological system as a whole. Also Cieślik et al. (2011) argue that in southern Poland many small and medium sized companies left milk production due to low profitability of the sector in recent years. According to Cederberg and Mattsson (2000) agricultural primary production has a zero or negative profitability. Organic farming is the key element to support agriculture in the Common Agricultural Policy of the European Union. Milk and dairy products in the EU are facing significant changes due to the enlargement of the EU (BouamraMechemache et al., 2008). The specificity of these products - perishability, seasonality of demand and inelastic supply and demand are causing instability in the market of milk and milk products (Suzuki \& Kaiser, 2005). Sustainable production of milk and milk products requires farms that are economically viable, environmentally friendly and socially acceptable (Thomassen et al., 2009).

Most authors analysing the dairy sector have been dealing with the problem of further trade liberalization, which means a reduction of import barriers and subsidized exports see Lariviere and Meilke (1999), Cox et al. (1999), Shaw and Love (2001) and Donnellan and Westhoff (2002). The impact of the abolition of the milk quota system has been analysed too (Bouamra-Mechemache et al., 2008; Jongeneel \& Huettel, 2011; Graubner et al., 2011). Breustedt et al. (2011) argues that the effectiveness of ecological direct payments could fall with the abolition of the milk quota system, which represents a new challenge for designing targeted policies to support organic farming. De Frahan et al. (2011) show how dairy farms without quotas may react differently to price changes and structural changes that may take place within the milk and milk products. The removal of quotas and a reduction of $20 \%$ in milk prices keep aggregate milk supply and farm income at the level of the reference year of 2006. Kempen et al. (2011) suggest that the abolition of the milk quota regime is likely to cause an increase in milk production by an average of $4.4 \%$ in the EU-27 and a drop in milk prices by $10 \%$. Agricultural revenues will fall by an average of $1.6 \%$, as increasing production cannot be compensated by lower milk prices. Their results have also been supported by other studies, such as Réquillart et al. (2008) forecasting an increase in production of 5.2\% and a decline in prices of $11 \%$. Witzke and Tonini (2009) show a production increase of $3 \%$ and a decrease in prices by $7 \%$. Chantreuil et al. (2008) predict an increase in production by $4.8 \%$ and price reduction by 7\%. Hill and Kopp (2011) analysed the development of the dairy sector in the Czech Republic from 2002 to 2010 and revealed a positive impact of the EU accession on the profitability of milk production. Weldesenbet (2013) analysed vertical transmission of producer prices at wholesale and retail prices for raw milk in Slovakia. He argues that there is a feedback causality of resale milk prices and changes in retail prices cause changes in prices for raw milk, but producer prices do not adjust to shocks in the wholesale market. Retail prices respond faster to increased producer prices, but slower to a reduction in producer prices which means a reduction of consumer welfare because producers do not benefit from price declines, only absorb milk price increases.

The analysis is based on the Farm Accountancy Data Network (FADN). Standard output (SO) is the average monetary value of the agricultural output at farm-gate price of the product in the region. The SO is calculated by the member states, in euro per hectare or per head of livestock as an average value over a reference period (5 years). The paper analysed the sector of Specialist dairying. The special type of farming is coded as 450 as a part of Specialist dairying farming type (45). This type is a part of general farming type Specialist grazing livestock. By the Commission Regulation (EC) No $1242 / 2008$, the type of farming is Specialist dairying, when dairy cows $>3 / 4$ of total grazing livestock; grazing livestock $>1 / 3$ of grazing livestock and forage (EC, 2008).

This definition implies that it is the predominant focus and enterprises classified in milk production are not specialized to milk production only. Table 1 shows the actual proportion of milk production to total production. On average, this share is $70 \%$; with the proportion below average in most of the New Members States (NMS) - probably they are mixed production enterprises, with prevailing milk production - compared to countries such as Finland or the Netherlands, where the share of milk production exceeds $80 \%$.

There are many ways how to measure labour productivity. The choice between them depends on the purpose of measuring the productivity and also on the availability of data. Measures of productivity can be defined as single-factor or multi-factor productivity factors. Measures of productivity are usually based on gross output or value added (OECD, 2001). The basic equation for productivity measurement is expressed as a proportion of output to labour input. The specific content of these categories of indicators can construct a wide range of indicators of labour productivity. The output can be measured in monetary units (e.g. indicators of 
revenues, turnover, gross or net value added) and in kind units (pieces, physical or arbitrary units). Labour input can be expressed by the number of hours worked, workshifts, days, or an average number of employees (Synek, 2009).

Table 1 Share of milk production in 2011

\begin{tabular}{ll}
\hline Interval & Country (value) \\
\hline up to 0.5 & Slovakia (0.422) \\
$0.5-0.6$ & Romania (0.501); Czech Republic (0.505); \\
& $\begin{array}{l}\text { Slovenia (0.507); Hungary (0.517); Austria } \\
\text { (0.536); Lithuania (0.562) }\end{array}$ \\
& Poland (0.617); Estonia (0.623); Sweden (0.628); \\
& Latvia (0.634); Denmark (0.645); Luxembourg \\
& $(0.652) ;$ Germany (0.673); EU (0.698) \\
$0.7-0.8$ & France (0.705); Bulgaria (0.71); Ireland (0.718); \\
& Italy (0.721); United Kingdom (0.752); Belgium \\
& $(0.766) ;$ Portugal (0.786); Spain (0.799); \\
above 0.8 & Finland (0.826); Netherlands (0.834); Malta \\
& $(0.836)$ \\
\hline
\end{tabular}

Source: FADN, own calculation

In practice, labour productivity is usually characterized by corporate outputs (or their parts) per one worker or per hour worked. Definition of indicators of labour productivity in the literature and in business practice varies, for example, income per worker, value added per worker, revenue to wages, and added value to wages (Novotná \& Volek, 2008). Labour productivity from value added is recommended by a number of authors due to its independence from the volume of power consumption. The FADN outputs do not distinguish the total number of workers to those who are directly involved in the production of milk, so the number is supposed to be estimated by the proportion of milk production in total production (Eq. 1).

$A W U m=A W U * M P / T O$

where $A W U m=$ Total labour input corresponding to share of milk products [AWU]; $A W U=$ Total labour input $[A W U]$, FADN row SE010; $M P=$ Milk production [EUR], FADN row SE216; TO = Total output [EUR] (FADN row SE131).

The labour productivity in monetary terms in the milk sector is mainly affected by milk yield, the influence of the number of cows per worker and the price of milk. These effects can be organized in a hierarchical system (Figure 1). The joint effect of milk yield and number of cows per worker has influenced labour productivity in kind expression.

It can be assumed that there are groups of states in which the causal indicators take similar values within the EU. States will be aggregated into groups using the cluster analysis (Ward's method, Euclidean distance) based on the values of the average price, milk yield and number of cows per worker in the last year (2011). For these groups, causal influences to difference from the European average of labour productivity will be expressed using the logarithmic method.

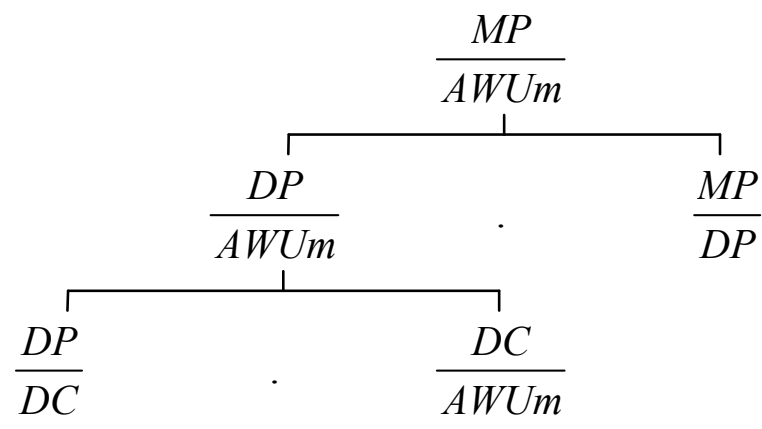

Figure 1 Decomposition of labour productivity

$D C=$ Average number of diary cows, FADN row SE125D

$D P=$ Production of milk (Diary Products) [kg], FADN row SE125N

$M P / A W U m=$ labour productivity in monetary expression

$[\mathrm{EUR} / \mathrm{AWU}]$

$D P / A W U m=$ labour productivity in kind expression [kg/AWU]

$M P / D P=$ average price of milk [EUR $/ \mathrm{kg}]$

$D P / D C=$ average annual milk yield per cow $[\mathrm{kg}]$

$D C / A W U m=$ number of cows per worker

\section{RESULTS AND DISCUSSION}

\section{Development of sales and prices for milk in the EU}

Germany is the largest milk producer in the EU. The share of milk production in the EU is around $20 \%$. France is the second largest milk producer in the EU and Great Britain is the third. The production of these three states is nearly $50 \%$ of total production (sales to dairies) in the EU and this share has declined since the enlargement only a little and mainly due to the growth of production in Germany. The fastest growth in sales of milk since 2001 was in Germany, followed by Poland and the Netherlands. Conversely, the biggest drop in sales of milk has occurred in Great Britain, Hungary and Sweden. In the Czech Republic the decline in sales of milk is the fourth largest. The Czech Republic is also the second largest producer of milk in the NMS, Poland is the first. The coefficient of variation shows the volatility of supply, which is high in NMS (Latvia, Bulgaria, Hungary, Estonia, Lithuania, Romania, and Poland). Low volatility of milk sales occurs in Spain and Portugal, the EU-15 ranges from $1.6 \%$ to $4.3 \%$; in the Czech Republic, the coefficient of variation of the milk supply achieves $3.99 \%$.

The development of producer prices of milk in the EU (Figure 2) has shown the variability in prices, with the coefficient of variation of average price at $8.5 \%$, with the lowest volatility of milk prices in France $(5.6 \%)$. The trend in the observed period shows an annual increase of 0.14 Euro $/ 100 \mathrm{~kg}$. The high variability $\mathrm{f}$ prices is reported mainly in the Baltic countries (about 20\%), Poland and Spain. The highest prices of milk producers occurred in Cyprus and Malta, which are not important producers in the EU. The lowest milk prices were reported in Lithuania, Latvia and Romania, where the greatest increase in milk prices was reported, with annual growth of more than 1 Euro/100 kg. Also in Spain, Poland and Estonia the rise in prices over 1 Euro/100 kg per year occurred. 


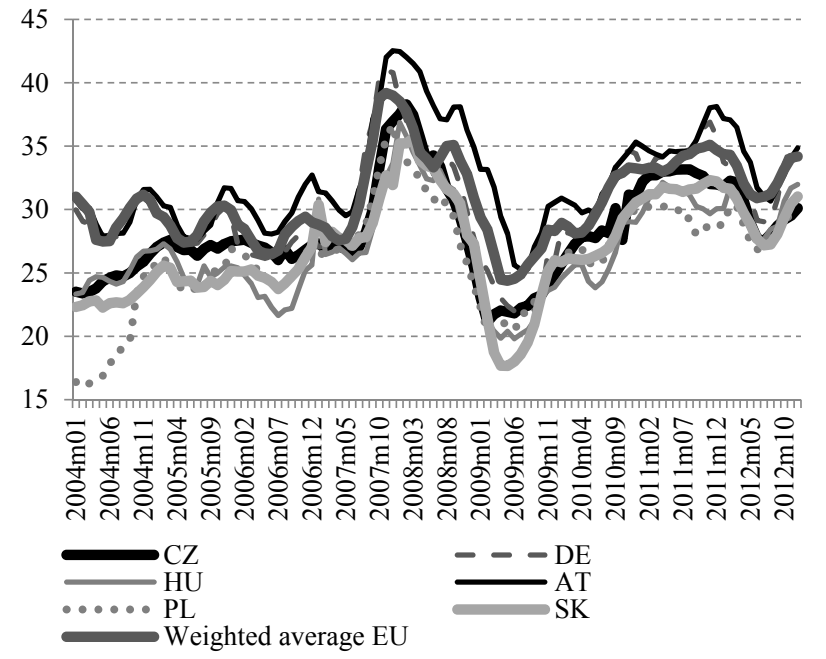

Figure 2 Development of producers' prices of milk (EUR/100kg).

Source: DG AGRI

Slightly downward trend in milk prices is shown in Portugal, Luxembourg and Italy. Despite the high variability, the annual increase in prices in the EU-15 (except Finland) does not exceed $0.5 \mathrm{EUR} / 100 \mathrm{~kg}$ and among the largest producers is close to zero. In the Czech Republic, prices of milk increased annually by 0.6 Euro $/ 100 \mathrm{~kg}$, the coefficient of variation is $11.7 \%$.

\section{Labour productivity}

Labour productivity is one of the crucial factors that form the overall economics of milk production. Labour productivity in monetary expression (measured from total revenues) divides the states into four different groups (Table 2). High differences in labour productivity between the first and the fourth group shows what differences exist between countries in terms of efficiency; coefficient of variation is $81.2 \%$. The Czech Republic and Slovakia reported similar values of labour productivity as the other NMS of Central and Eastern Europe. The Czech Republic reached $66 \%$ of average labour productivity in the EU.

Figure 3 shows the development of labour productivity in monetary terms, the Czech Republic and neighbouring countries as well as Europe's largest producers of milk. In 2007, a noticeable decrease in average labour productivity in the EU-27 due to the accession of states with very low labour productivity was reported. Since 2004, the gap in labour productivity between the Czech Republic and the EU improved from $48 \%$ to $66 \%$.

Labour productivity in monetary expression (only of revenues from milk) can be divided into a various subfactors, namely the impact of number of cows per worker, influence of milk yield (together the labour productivity in kind terms) and the effect of the price. The indicators are connected multiplicatively and therefore positive but also negative could be mutually accelerated or compensated.
Table 2 Distribution of labour productivity in monetary expression in 2011

\begin{tabular}{|c|c|}
\hline Interval & Country (value in EUR/AWU) \\
\hline up to 10000 & Romania (7039); Bulgaria (7710) \\
\hline $10000-50000$ & $\begin{array}{lll}\text { Lithuania (16393); Latvia } & (17335) ; \\
\text { Poland (18680); Slovenia } & (27213) ; \\
\text { Slovakia (33166); Czech } & \text { Republic } \\
\text { (39800); Austria (42096); } & \text { Hungary } \\
\text { (43495); Portugal (43761) } & \end{array}$ \\
\hline $50000-100000$ & $\begin{array}{l}\text { Estonia (51224); EU (60259); Finland } \\
\text { (66315); Spain (67769); Malta (91838); } \\
\text { Italy (96611); France (98988); Ireland } \\
\text { (99974) }\end{array}$ \\
\hline above 100000 & $\begin{array}{l}\text { Belgium (102629); Germany (105988); } \\
\text { Luxembourg (117070); United Kingdom }\end{array}$ \\
\hline & $\begin{array}{lll}(146177) ; & \text { Sweden } & (147702) ; \\
\text { Netherlands } & (179647) ; & \text { Denmark } \\
(291309) & & \end{array}$ \\
\hline
\end{tabular}

Source: FADN, own calculation

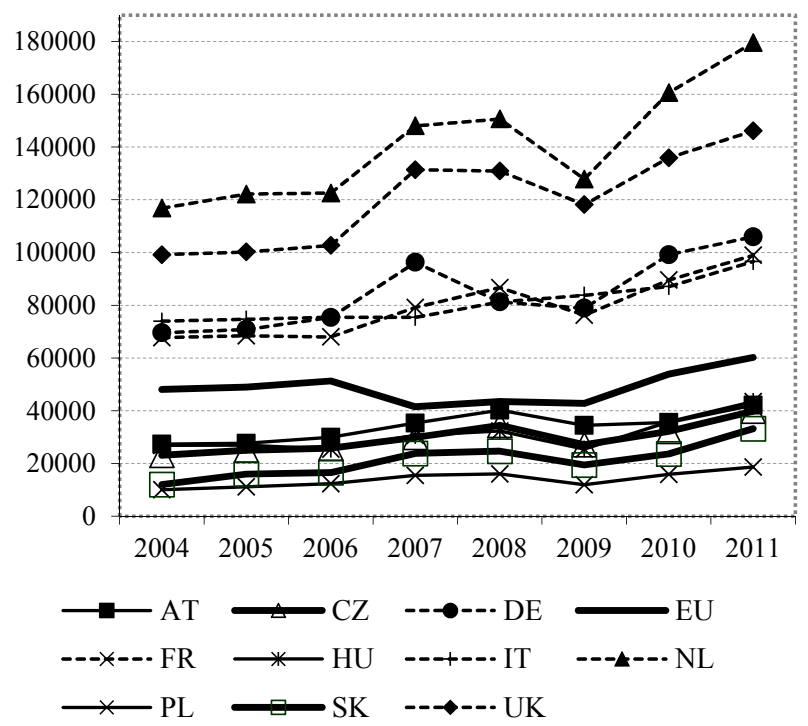

Figure 3 Labour productivity in monetary expression [EUR/AWU].

Source: FADN, own calculation

Labour productivity in kind expression follows a similar trend as in monetary terms. In the NMS of Central and Eastern Europe, labour productivity in kind terms is without any exception below the average: 118 t/AWUm in the Czech Republic compared to 171 $\mathrm{t} / \mathrm{AWUm}$ in the EU-27 in 2011. High productivity was achieved in Denmark (784 t/AWUm), United Kingdom (464 t/AWUm) and the Netherlands (454 t/AWUm). The coefficient of variation of labour productivity in kind terms is $76.9 \%$ (2011).

There is a significant difference in a number of dairy cows per worker between the EU member states. In Romania, 6.7 cows per a worker were reported and 8.4 cows in Bulgaria. On the other hand, Denmark reported 93.1 cows/worker and 62.4 cows/worker occurred in United Kingdom. Number of dairy cows per worker in the NMS of Central and Eastern Europe was below the average without any exception. The EU average is 25.1 
cow/worker; in the Czech Republic the value of 18.4 cows per worker was reported; with the coefficient of variation of $64.6 \%$. The development of indicators after 2004 cannot report any significant trends.

The average milk yield achieved $6804 \mathrm{~kg} / \mathrm{cow}$ in the EU, the NMS of Central and Eastern Europe reached only below average values (6443 kg in the Czech Republic, $5423 \mathrm{~kg}$ in Slovakia), the variability among states is low, with the coefficient of variation of $21.9 \%$. Average yields in the EU in the period $2004-2011$ increased by $66 \mathrm{~kg}$ per year.

The average price of milk (measured from FADN as proportion of milk product in EUR and in $\mathrm{kg}$ ) was $0.353 \mathrm{EUR} / \mathrm{kg}$ in the EU in 2011. The above-average values were reported only in Denmark (0.372), Sweden (0.386), the Netherlands (0.395), Finland (0.411), Malta $(0.462)$ and Italy $(0.484)$. Variability of prices between states is the lowest among the analytical indicators described, with the coefficient of variation of $15.3 \%$. The minimum value was reported in Lithuania (0.269).

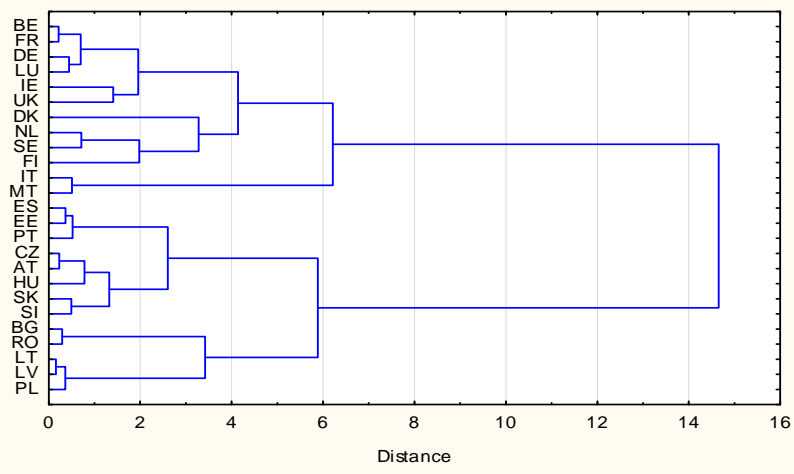

Figure 4 Hierarchical tree plot of EU countries. Source: FADN, own calculation

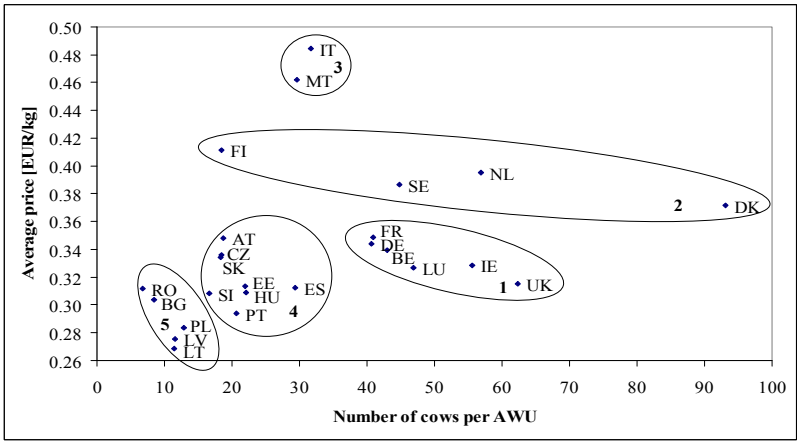

Figure 5 Clusters according to price and number of cows per worker.

Source: FADN, own calculation

Figure 4 expresses the results of hierarchical clustering of states by milk prices, yields and the number of cows per worker. To analyse the effect of these parameters on the difference in labour productivity 5 clusters were selected. The interrelation of milk prices and the number of cows per worker and the clusters is revealed in Figure 5. The average values of labour productivity and causal indicators in clusters are listed in Table 3.

Cluster 1 consists of Belgium, France, Germany, Luxembourg, Ireland and Great Britain. These states participated by $55.5 \%$ in the European production in
2011. Labour productivity in this group exceeded the European average by 48410 EUR, with the most important influence of the number of cows per worker (48202 EUR), the effect of milk yield was low (3704 EUR) and price effect was negative ( -3496 EUR).

Table 3 Average values of indicators in clusters

\begin{tabular}{ccccccr}
\hline Cluster & $\begin{array}{l}\text { Labour } \\
\text { producti- } \\
\text { vity }\end{array}$ & $\begin{array}{l}\text { Labour } \\
\text { producti- } \\
\text { vity } \\
\text { EUR/AWU } \\
\text { kg/AWUm }\end{array}$ & $\begin{array}{l}\text { Average } \\
\text { price } \\
\text { EUR/kg }\end{array}$ & $\begin{array}{l}\text { Milk } \\
\text { yield } \\
\text { kg per } \\
\text { cow }\end{array}$ & $\begin{array}{l}\text { Cows per } \\
\text { worker } \\
\text { pc/AWUm }\end{array}$ \\
\hline 1 & 108669 & 321475 & 0.338 & 7118 & 45.2 \\
2 & 153147 & 391708 & 0.391 & 8236 & 47.6 \\
3 & 96591 & 199450 & 0.484 & 6291 & 31.7 \\
4 & 49352 & 154705 & 0.319 & 6863 & 22.5 \\
5 & 13458 & 46776 & 0.288 & 4583 & 10.2 \\
\hline
\end{tabular}

Source: FADN, own calculation

Cluster 2 (Denmark, the Netherlands, Sweden and Finland), participated by $15.5 \%$ in the European production in 2011. Labour productivity exceeded the European average by 92888 EUR. The number of cows per worker (63620 EUR) was the most important. Other influence reported lower intensity. High milk yield increased productivity by 19020 EUR and the average price by 10248 EUR.

Cluster 3 includes Italy and Malta and is typical for the high price of milk $(0.484 \mathrm{EUR} / \mathrm{kg})$. Aboveaverage productivity (about 36331 EUR) is explained by higher price (24405 EUR). Effect of productivity in kind terms reported 11926 EUR, and can be divided into positive impact of cows per worker (17961 EUR), which is partly absorbed by lower milk yields ( -6035 EUR).

Cluster 4 consists of the original (Spain, Portugal) and the New Member States (Estonia, the Czech Republic, Hungary, Slovakia and Slovenia). Labour productivity in this group lags behind the European average of 10907 EUR. The only positive effect was reported in milk yield (470 EUR). Lower prices explain the difference of -5490 EUR and lower number of cows per worker (-5886 EUR).

Cluster 5 contains five New Member States (Romania, Bulgaria, Lithuania, Latvia and Poland), where the average productivity lags behind the European average by 46801 EUR. In this group, all causal indicators were below the average and thus acted negatively on the differences in productivity. The number of cows per worker $(-28102$ EUR) was the most important with lower milk yield (-12338 EUR) as well as the effect of lower prices (-6361 EUR).

The number of cows per worker is decisive factor explaining labour productivity in all clusters. The price of milk significantly affected productivity only in clusters 3 and 4 . The level of monetization had an influence on the overall labour productivity neither in the original states of the EU, nor in states with belowaverage prices. 


\section{CONCLUSIONS}

Milk production in Germany, France and Great Britain is nearly $50 \%$ of the total production of the EU. Due to the growth of production in Germany, this share has fallen only marginally after the EU enlargement. The greatest increase in milk production was reported in Germany since 2001, followed by Poland and the Netherlands. Conversely, the biggest drop in sales of milk was reported in Great Britain, Hungary and Sweden. The fourth largest decline in milk production occurred in the Czech Republic, which is the second largest producer of milk in the New Member States after Poland. The development of producer prices of milk in the EU has shown variability in prices since 2001 with the coefficient of variation of average prices of $8.5 \%$. The lowest volatility of milk prices was in France (5.6\%) and the trend in the observed period shows an annual increase of $0.14 \mathrm{EUR} / 100 \mathrm{~kg}$. The high variability of prices was observed mainly in the Baltic countries (about 20\%), Poland and Spain.

The number of cows per worker is one of the most important factors affecting productivity. Multiplicative relation between the number of cows per worker and milk yield increases their importance to the level of labour productivity in terms of in-kind volume. Effect of prices on labour productivity in monetary expression is not as significant as is usually assumed.

Low number of cows per worker in some countries raises the question of the higher concentration of production in dairy production. The technical equipment of labour, i.e. the volume of tangible assets per worker should be an important factor influencing the number of cows per worker (as a determinant of labour productivity). The hypothesis that higher technical equipment of labour should create better conditions for higher productivity could be assumed. Technical equipment of labour can be increased with the investment support in the modernization of agricultural holdings from European sources. The verification of this hypothesis is difficult by different pricing of buildings and technological equipment in the international comparison and consequently is not performed.

Acknowledgements: The authors thank the Ministry of Education of the Czech Republic for financial support, Research Program of the Department of Accounting and Finance (RVO 160).

\section{REFERENCES}

BOUAMRA-MECHEMACHE, Z. - JONGENEEL, R. RÉQUILLART, V. 2008. Impact of a gradual increase in milk quotas on the EU dairy sector. European Review of Agricultural Economics, 35, 461-491. doi: $\underline{10.1093 / \mathrm{erae} / \mathrm{jbn} 044}$

BREUSTEDT, G. - LATACZ-LOHMANN, U. TIEDEMANN, T. 2011. Organic or conventional? Optimal dairy farming technology under the EU milk quota system and organic subsidies. Food Policy, 36(2), 223-229. doi: 10.1016/j.foodpol.2010.11.019
CEDERBERG, CH. - MATTSSON, B. 2000. Life cycle assessment of milk production - a comparison of conventional and organic farming. Journal of Cleaner Production, 8(1), 49-60. doi: 10.1016/S09596526(99)00311-X

CIEŚLIK, J. - BADACH, E. - KRASNODĘBSKI, A. 2011. Purposefulness of a more intensive supporting milk production in conditions of dispersed agriculture of Southern Poland. Agricultural Economics - Zemèdělská ekonomika, 57(4), 196-202.

COX, T. L. - COLEMAN, J. R. - CHAVAS, J. P. - ZHU, Y. 1999. An economic analysis of the effects on the world dairy sector of extending Uruguay Round Agreement to 2005. Canadian Journal of Agricultural Economics, $\quad 47(5), \quad 169-183$. http://dx.doi.org/10.1111/j.1744-7976.1999.tb00257.x DE FRAHAN, B. H. - BAUDRY, A. - DE BLANDER, R. - POLOMÉ, P. - HOWITT, R. 2011. Dairy farms without quotas in Belgium: estimation and simulation with a flexible cost function. European Review of Agricultural Economics, 38 (4), 469-495. doi: $\underline{10.1093 / \text { erae/jbr013 }}$

DONNELLAN T. - WESTHOFF P. 2002. World dairy trade reform: perspectives from Europe and the USA. Bulletin of the International Dairy Federation, 376, 72 88.

DOUBEK, V. - ŠVASTA, J. - ACKERMANN BLAŽKOVÁ, L. 2012. Agricultural trade on the example of milk from the perspective of the multi-criteria analysis. Agricultural Economics - Zemédělská ekonomika, 58(7), 315-323.

EUR-Lex, Access to European Union law, Commission Regulation (EC) No 1242/2008 of 8. December 2008. Retrieved from http://eur-lex.europa.eu

EUROPEAN COMMISSION 2014. Report of the Conference: The EU Dairy Sector: Developing Beyond 2015. (Brussels 24. 9. 2013). Retrieved from http://ec.europa.eu/agriculture/index_en.htm

GRAUBNER, M. - KOLLER, I. - SALHOFER, K. BALMANN, A. 2011. Cooperative versus noncooperative spatial competition for milk. European Review of Agricultural Economics, 38(1), 99-118. doi: 10.1093/erae/jbq054

HUETTEL, S. - JONGENEEL, R. 2011. How has the EU milk quota affected patterns of herd-size change? European Review of Agricultural Economics, 38(4), 497-527. doi: $10.1093 / \mathrm{erae} / \mathrm{jbq} 050$

CHANTREUIL, F. - DONNELLAN, T. - VAN LEEUWEN, M. - SALAMON, P. - TABEAU, A. BÁRTOVÁ. L. 2008. EU dairy quota reform AGMEMOD scenario analysis. In 12th Congress of the European Association of Agricultural Economists EAAE, University of Ghent, Belgium, $26-29$ August 2008. Retrieved from http://purl.umn.edu/43655

INTERNATIONAL FARM COMPARISON NETWORK. Overview on milk prices and production costs world wide 2013. Dairy Report 2013. Retrieved from

http://www.ifcndairy.org/en/the ifcn/welcome/index.php KEMPEN, M. - WITZKE, P. - PÉREZ DOMÍNGUEZ, I. - JANSSON, T. - SCKOKAI, P. 2011. Economic and 
environmental impacts of milk quota reform in Europe. Journal of Policy Modeling, 33(1), 29-52. doi: http://dx.doi.org/10.1016/j.jpolmod.2010.10.007

LARIVIĖRE, S. - MEILKE, K. 1999. An assessment of partial dairy trade liberalization on the U.S., EU-15 and Canada. Canadian Journal of Agricultural Economics, 47(5), 59-73. $\quad$ http://dx.doi.org/10.1111/j.17447976.1999.tb00241.x

MINISTRY OF AGRICULTURE, THE CZECH REPUBLIC 2014. Situační a výhledová zpráva Mléko 2013. Retrieved from http://eagri.cz/public/web/mze/zemedelstvi/publikace-adokumenty/

NOVOTNÁ, M. - VOLEK, T. 2008. Měření efektivnosti využívání výrobních faktorů v souvislostech. České Budějovice: Jihočeská univerzita, 2008. ISBN 978-807394-126-0.

OECD Measuring Productivity. Measurement of aggregate and industry-level productivity growth. OECD Manual, 2001. Retrieved from http://www.oecd.org/std/productivity-stats/2352458.pdf . RÉQUILLART, V. - BOUAMRA-MECHEMACHE, Z. JONGENEEL, R., - PENEL, C. 2008. Economic analysis of the effects of the expiry of the EU milk quota system. Report prepared for the European Commission, IDEI, Retrieved from http://ec.europa.eu/agriculture/analysis/external/milk/full text en.pdf
SHAW, I. - LOVE, G. 2001. Impacts of liberalising world trade in dairy products. Australian Bureau of Agricultural and Resource Economics, ABARE Research Report 01.4. Canberra: ABARE, 2001. Retrieved from http://data.daff.gov.au/anrdl/metadata files/pe abarebrs9 9000650.xml

SUZUKI N. - KAISER H. M. 2005. Impacts of the Doha Round framework agreements on dairy policies. Journal of Dairy Science, 88(5), 1901-1908. http://dx.doi.org/10.3168/jds.S0022-0302(05)72866-6 SYNEK, M. - KOPKÁNĚ, H. - KUBÁLKOVÁ, M. 2009. Manažerské výpočty a ekonomická analýza. Praha: C.H.Beck, 2009. ISBN 978-80-7400-154-3.

THOMASSEN, M. A. - DOLMAN, M. A. - VAN CALKER, K. J. - DE BOER, J. M. 2009. Relating life cycle assessment indicators to gross value added for Dutch dairy farms. Ecological Economics, 68(8-9), 2278-2284. doi: http://dx.doi.org/10.1016/j.ecolecon.2009.02.011

WELDESENBET, T. 2013. Asymmetric price transmission in the Slovak liquid milk market. Agricultural Economics - Zemédělská ekonomika, 59(11), 512-524.

WITZKE, H. P. - TONINI, A. 2009. Milk quota expiry impacts and sensitivity analyses using the CAPSIM model. German Journal of Agricultural Economics, 58(5/6), 228-237. 